\title{
Enhanced Anandamide Plasma Levels in Patients with Complex Regional Pain Syndrome following Traumatic Injury: A Preliminary Report
}

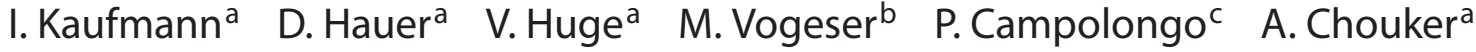 \\ M. Thiel ${ }^{a} \quad$ G. Schelling ${ }^{a}$
}

Departments of anesthesiology and ${ }^{\mathrm{b}} \mathrm{Clinical}$ Chemistry, Ludwig Maximilians University, Munich, Germany;

'Department of Human Physiology and Pharmacology, University of Rome La Sapienza, Rome, Italy

\section{Key Words}

Complex regional pain syndrome $\cdot$ Stress $\cdot$ Pain .

Endocannabinoid $\cdot$ Anandamide

\begin{abstract}
The complex regional pain syndrome (CRPS) is a disabling neuropathic pain condition that may develop following injuries of the extremities. The pathogenesis of this syndrome is not clear; however, it includes complex interactions between the nervous and the immune system resulting in chronic inflammation, pain and trophic changes. This interaction may be mediated by chronic stress which is thought to activate the endogenous cannabinoid (endocannabinoid) system (ECS). We conducted an open, prospective, comparative clinical study to determine plasma level of the endocannabinoid anandamide by high-performance liquid chromatography and a tandem mass spectrometry system in 10 patients with CRPS type I versus 10 age- and sexmatched healthy controls. As compared to healthy controls, CRPS patients showed significantly higher plasma concentrations of anandamide. These results indicate that the peripheral ECS is activated in CRPS. Further studies are warranted to evaluate the role of the ECS in the limitation of inflammation and pain.

Copyright $\odot 2009$ S. Karger AG, Basel
\end{abstract}

I.K. and D.H. contributed equally to this work.

\section{Introduction}

The complex regional pain syndrome (CRPS) is characterized by neuropathic pain, sensory disturbances, trophic, autonomic and motor changes of the affected extremity $[1,2]$. The pathogenesis of this syndrome may include abnormal neuronal processing and central sensitization [3-5] as well as complex communications between the nervous and the immune system resulting in chronic inflammation, pain and trophic changes [6] which are mediated in part by catecholamines and stress $[7,8]$. The endocannabinoid system (ECS) has recently been shown to represent a critical mediator between stress, neuropathic pain and immunologic changes including neuroinflammation [9] and may therefore play a role in the development and symptom persistence in CRPS. The ECS includes the endocannabinoids anandamide and 2-arachidonoylglycerol (2-AG) [10] which are functionally related to $\Delta^{9}$-tetrahydrocannabinol. Two different types of $G$ protein-coupled receptors, namely $\mathrm{CB}_{1}$ receptors which are found mainly in the central nervous system [11] and $\mathrm{CB}_{2}$ receptors with a peripheral distribution, especially on immunocompetent cells $[12,13]$, and the transient receptor potential vanilloid 1 (TRPV1) channels [14] mediate the effects of the endocannabinoids. Based on experiments in rodents, both $\mathrm{CB}_{1}$ and $\mathrm{CB}_{2}$ receptors participate in central and peripheral cannabinoid-induced analgesia $[15,16]$ and anti-inflamma-

Manfred Thiel, MD, PhD, Department of Anesthesiology

Klinikum Großhadern, Ludwig Maximilians University

Marchioninistrasse 15, DE-81366 Munich (Germany)

Tel. +49 89 7095-1, Fax +498970958886

E-Mail manfred.thiel@med.uni-muenchen.de 
tion $[17,18]$, and appear to be activated under conditions of stress $[9,19]$. The TRPV1 channel is involved in the control of neurotransmitter release [14].

Very little is known about the role of the ECS in humans with neuropathic pain in general and with CRPS in particular. We therefore measured the endocannabinoid anandamide in plasma of patients with CRPS. Our primary hypothesis to be tested was that the peripheral ECS is activated, and thus anandamide levels are elevated in patients with CRPS compared to healthy participants.

\section{Materials and Methods}

\section{Patients}

Ten female CRPS type I patients $(46.0 \pm 10.7$ years, range 20-55) admitted to the Interdisciplinary Pain Clinic of the Department of Anesthesiology of the University of Munich, Germany, were enrolled for blood withdrawal (table 1) if they provided informed consent (local ethics committee protocol No. 324/02) and met the criteria for CRPS type I as proposed by the International Association for the Study of Pain [20] and Bruehl et al. [21]. Ten age- and sex-matched healthy individuals (7 female, 3 male; $41.9 \pm 7.3$ years, range $34-50$ ) who were completely free of medication served as controls. Exclusion criteria were pregnancy, infection or other inflammation disorders, cancer, muscle or joint diseases, motor trauma and treatment with glucocorticoids or other immunosuppressive drugs. All subjects had abstained from their medication for at least $24 \mathrm{~h}$ before blood sampling. In CRPS patients, we determined the duration and localization of the disorder, and the pain intensities on a visual analogue scale (pain scores, $10-\mathrm{cm}$ scale). The Mainz Pain Staging System was used to classify pain chronicity [22]. The incidence and intensity of chronic stress symptoms were evaluated by the Posttraumatic Stress Symptom-10 questionnaire [23].

Biochemical Measurements and Anandamide Determination

All biochemical measurements were conducted in a blinded fashion with regard to group assignment of patients and controls. Venous blood sampling $(500 \mu \mathrm{l})$ was performed from the unaffected limb. Because of effects of circadian rhythm on endocrine measurements, the time point of blood sampling during the day was standardized (between 10 and 11 a.m.) as was the time interval from blood sampling until processing which ranged from 7 to 10 min and did not differ between the groups ( $p>0.50)$. This time interval is particularly important with regard to endocannabinoid measurements [24].

For determination of anandamide concentrations, we applied automated on-line solid phase extraction using column switching with subsequent direct transfer to high-performance liquid chromatography and a tandem mass spectrometry system (Waters Quattro Ultima Pt; Waters Corporation, Milford, Mass., USA) with stable isotope-labeled anandamide (4-fold deuterated) as the internal standard. Electrospray ionization in the positive mode was used; the following mass transitions were monitored: native anandamide, $348>62$ and $4 \mathrm{~d} 3$-anandamide (internal standard), $352>66$. Our method has a linear response from 100 to $1 \mu \mathrm{g} / \mathrm{l}$ anandamide and a total coefficient of variation of $10.6 \%$ at a mean concentration of $8.5 \mu \mathrm{g} / \mathrm{l}$ [24].

Furthermore, a standard set of laboratory values (hemoglobin, leukocyte counts, C-reactive protein) was measured in both patients and healthy controls.

\section{Statistics}

Normal distribution of sample data was confirmed by the Kolmogorov-Smirnov test. Geometric means were compared by Student's t test and considered to be significantly different at $\mathrm{p}<0.05$. Results are expressed as means \pm standard deviation.

\section{Results}

\section{Patient Characterization}

There was no significant difference with regard to age $(46.0 \pm 10.7$ years, range $20-55$ vs. $41.9 \pm 7.3$ years, range $34-50 ; \mathrm{p}=0.33)$ and sex distribution $(\mathrm{p}=0.21)$ between CRPS patients and controls.

CRPS patients had a mean disease duration of 22 months. The mean pain score in CRPS patients was 3.9 \pm 0.5 on the $10-\mathrm{cm}$ visual analogue scale. According to the criteria of the Mainz Pain Staging System classification, 3 patients belonged to stage I, 4 patients had pain chronicity of stage II and 3 patients fulfilled criteria for advanced pain chronification (stage III). The Posttraumatic Stress Symptom-10 score in the CRPS study population was higher $(35.2 \pm 5.3)$ than in healthy controls $(20.8 \pm 4.8 ; \mathrm{p}<0.01)$.

\section{Standard Laboratory Values}

The standard set of laboratory values in patients with CRPS was in the normal range and not statistically different from healthy controls (data not shown).

\section{Anandamide Concentrations}

CRPS patients had significantly higher plasma concentrations $(3.97 \pm 1.49 \mathrm{ng} / \mathrm{ml})$ of anandamide than healthy controls $(1.44 \pm 0.36 \mathrm{ng} / \mathrm{ml}$; $\mathrm{p}<0.001$; $95 \%$ confidence interval -3.55 to -1.51 ; fig. 1$)$. The power of the performed test with $\alpha=0.05$ is 0.999 .

\section{Discussion}

The major finding of this study is an increased plasma concentration of the endocannabinoid anandamide in patients with a long-standing and chronic neuropathic pain syndrome, namely CRPS. Chronic stress as a result of ongoing neuropathic pain or stressful life events is a 
Table 1. Age distribution and underlying trauma in the CRPS study population

\begin{tabular}{llll}
\hline $\begin{array}{l}\text { Patient } \\
\text { No. }\end{array}$ & $\begin{array}{l}\text { Age } \\
\text { years }\end{array}$ & $\begin{array}{l}\text { Disease } \\
\text { duration } \\
\text { months }\end{array}$ & Trauma before ongoing of CRPS \\
\hline 1 & 53 & 20 & distal radial fracture \\
2 & 49 & 53 & lateral meniscal lesion \\
3 & 36 & 92 & epicondylitis humeroscapularis \\
4 & 53 & 25 & cubital tunnel syndrome \\
5 & 52 & 5 & rhizarthrosis \\
6 & 50 & 3 & scaphoidal fracture \\
7 & 48 & 8 & Weber C fracture \\
8 & 44 & 3 & distal radial fracture \\
9 & 20 & 10 & contusion of the knee and lower leg \\
10 & 55 & 3 & carpal tunnel syndrome \\
\hline
\end{tabular}

common finding in CRPS patients [7, 25], and our patients showed high stress symptoms scores and evidence of long-lasting chronic neuropathic pain.

Anandamide found in peripheral blood is synthesized by nucleated blood cells [24]; the primary stimulus leading to increased endocannabinoid synthesis in blood cells is, however, unknown. The peripheral ECS in humans has been shown to be activated by stressful physical exercise [26] and deactivated by the induction of general anesthesia which leads to a pronounced stress reduction [27]. Furthermore, elevated anandamide levels have been described in patients with a stress-related disorder, namely fibromyalgia [28]. Likewise, in animals, massive emotional stress has been identified as a key stimulus regulating endocannabinoid synthesis [29].

The pathophysiological relevance of the enhanced anandamide levels in CRPS patients is still unclear. Using various experimental paradigms which involved stress, pain and memory [30-32], inhibitory endocannabinoid activity has been demonstrated in the amygdala, a key brain area for the encoding and consolidation of traumatic information [33]. One could therefore speculate that the increased activity of the peripheral ECS observed in our study is related to continuous stress exposure and suggests a possible protective role for the ECS in the modulation of neuropathic pain and pain memory [34]. These protective effects of endocannabinoids may also include stress-induced analgesia, both on a central [35] and a peripheral level [15]. Using murine models, stress induced a rapid anandamide release in several central nervous system regions resulting in stress-induced analgesia via $\mathrm{CB}_{1}$

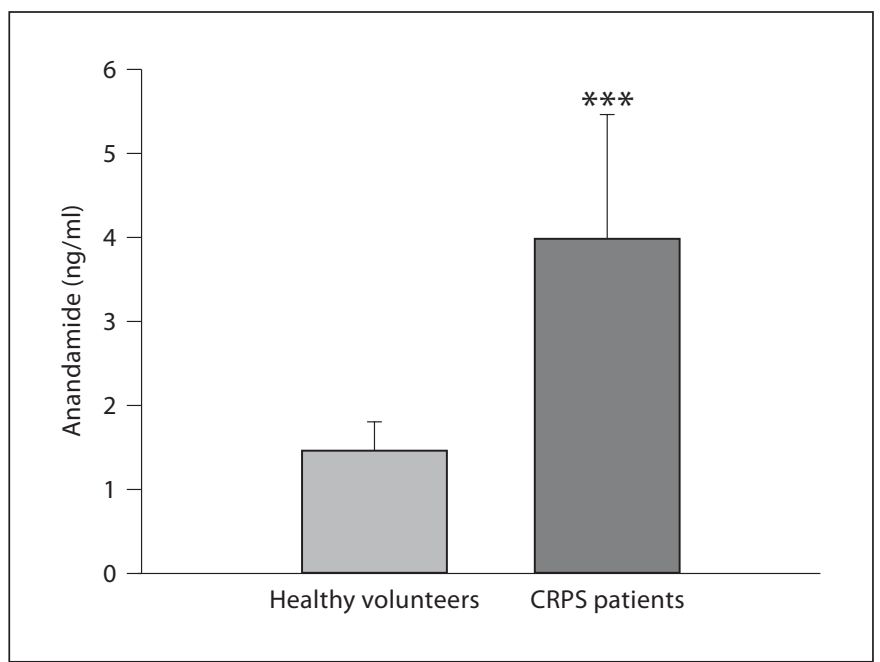

Fig. 1. Comparison of anandamide plasma levels between CRPS patients and age- and sex-matched healthy controls (10 subjects each). ${ }^{* *} \mathrm{p}<0.001$, Student's $\mathrm{t}$ test. To convert $\mathrm{ng} / \mathrm{ml}$ to $\mathrm{pmol} / \mathrm{ml}$, multiply by 2.9. Data are means \pm standard deviation.

receptors $[35,36]$. In addition, a very recent study has shown that endocannabinoids mediate analgesia via stimulation of peripheral $\mathrm{CB}_{1}$ receptors in mice [15].

A further protective effect of the ECS may result from well-known anti-inflammatory effects via $\mathrm{CB}_{2}$ receptors [37] on a variety of innate and adaptive immune functions [38]. Animal and in vitro experiments revealed that cellular effects of cannabinoids include modulation of chemotaxis of macrophage-like cells [39], migration of natural killer cells [40], modification of oxidative burst of neutrophils [41], and attenuation of B and $\mathrm{T}$ cell subset formations [42], thereby contributing to anti-inflammatory host defense mechanisms of the organism. In fact, inflammation control by enhanced anandamide levels has been described for experimentally induced colon inflammation [43], cholera toxin-induced diarrhea [44], and in patients with inflammatory gastrointestinal diseases [45]. In patients with another stress-related disorder, namely fibromyalgia, a strong, positive relationship between anandamide levels and the adhesive and phagocytic functions of neutrophils was found. Moreover, multiple backward regression analysis revealed plasma concentration of anandamide to be the main factor in determining adhesion and phagocytosis capacity of neutrophils [28]. Thus, the upregulation of peripheral anandamide levels seen in our patients might be regarded as an endogenous mechanism to protect from pain and to limit inflammation. 
Our study has several limitations, however. We studied only a small number of subjects, and this makes it difficult to generalize our findings to other patient groups with CRPS. Additionally, interindividual differences preponderate in such small patient groups. On the other hand, the patient and the control groups in our study were well matched, and the differences between both groups with regard to the hypothesis under study were large and statistically significant. A further limitation is that we determined only anandamide and did not measure other important endocannabinoids such as 2-AG. The determination of 2-AG carries several methodologi- cal problems, however, which result from spontaneous isomerization to biologically inactive $1-A G[46,47]$ which may occur in vivo and in vitro with the consequence of imprecise measurements [48].

In conclusion, our study has shown for the first time that the peripheral ECS is activated in highly stressed individuals with CRPS. With respect to the pain-limiting and anti-inflammatory actions of the endocannabinoid anandamide, it is suggested that the elevated anandamide level is probably autoprotective and CRPS patients might therefore benefit from pharmacologic manipulation of cannabinoid receptor-dependent signaling.

\section{References}

1 Birklein F: Complex regional pain syndrome. J Neurol 2005;252:131-138.

2 Harden RN, Bruehl S, Stanton-Hicks M, Wilson PR: Proposed new diagnostic criteria for complex regional pain syndrome. Pain Med 2007;8:326-331.

3 Jänig W, Baron R: Complex regional pain syndrome: mystery explained? Lancet Neurol 2003;2:687-697.

4 Juottonen K, Gockel M, Silen T, Hurri H, Hari R, Forss N: Altered central sensorimotor processing in patients with complex regional pain syndrome. Pain 2002;98:315323.

5 Maihöfner C, Baron R, Decol R, Binder A, Birklein F, Deuschl G, Handwerker HO, Schattschneider J: The motor system shows adaptive changes in complex regional pain syndrome. Brain 2007;130:2671-2687.

6 McMahon SB, Cafferty WBJ, Marchand F: Immune and glial cell factors as pain mediators and modulators. Exp Neurol 2005;192: 444-462.

7 Drummond PD, Finch PM, Skipworth S, Blockey P: Pain increases during sympathetic arousal in patients with complex regional pain syndrome. Neurology 2001;57:12961303.

8 Kaufmann I, Eisner C, Richter P, Huge V, Beyer A, Chouker A, Schelling G, Thiel M: Psychoneuroendocrine stress response may impair neutrophil function in complex regional pain syndrome. Clin Immunol 2007; 125:103-111.

9 Carrier EJ, Patel S, Hillard CJ: Endocannabinoids in neuroimmunology and stress. Curr Drug Targets CNS Neurol Disord 2005;4: 657-665.

10 Grotenhermen F: Pharmacology of cannabinoids. Neuro Endocrinol Lett 2004;25:1423.
11 Matsuda LA, Lolait SJ, Brownstein MJ, Young AC, Bonner TI: Structure of a cannabinoid receptor and functional expression of the cloned cDNA. Nature 1990;346:561564.

12 Galiegue S, Mary S, Marchand J, Dussossoy D, Carriere D, Carayon P, Bouaboula M, Shire D, Le Fur G, Casellas P: Expression of central and peripheral cannabinoid receptors in human immune tissues and leukocyte subpopulations. Eur J Biochem 1995;232: 54-61.

13 Schatz AR, Lee M, Condie RB, Pulaski JT, Kaminski NE: Cannabinoid receptors $\mathrm{CB}_{1}$ and $\mathrm{CB}_{2}$ : a characterization of expression and adenylate cyclase modulation within the immune system. Toxicol Appl Pharmacol 1997;142:278-287.

14 Van der Stelt M, Trevisani M, Vellani V, De Petrocellis L, Moriello AS, Campi C, McNaughton P, Geppetti P, Di Marzo V: Anandamide acts as intracellular messenger amplifying $\mathrm{Ca}^{2+}$ influx via TRPV1 channels EMBO J 2005;24:3026-3037.

15 Agarwal N, Pacher P, Tegeder I, Amaya F, Constantin CE, Brenner GJ, Rubino T, Michalski CW, Marsicano G, Monory K, Mackie K, Marian C, Batkai S, Parolaro D, Fischer MJ, Reeh P, Kunos G, Kress M, Lutz B, Woolf CJ, Kuner R: Cannabinoids mediate analgesia largely via peripheral type 1 cannabinoid receptors in nociceptors. Nat Neurosci 2007; 10:870-879.

16 Ibrahim MM, Rude ML, Stagg NJ, Mata HP Lai J, Vanderah TW, Porreca F, Buckley NE, Makriyannis A, Malan TP: $\mathrm{CB}_{2}$ cannabinoid receptor mediation of antinociception. Pain 2006;122:36-42.

17 Batkai S, Osei-Hyiaman D, Pan H, El Assal O, Rajesh M, Mukhopadhyay P, Hong F, Harvey-White J, Jafri A, Hasko G, Huffman JW, Gao B, Kunos G, Pacher P: Cannabinoid2 receptor mediates protection against hepatic ischemia/reperfusion injury. FASEB J 2007;21:1788-1800.
18 Maresz K, Pryce G, Ponomarev ED, Marsicano G, Croxford JL, Shriver LP, Ledent C, Cheng X, Carrier EJ, Mann MK, Giovannoni G, Pertwee RG, Yamamura T, Buckley NE, Hillard CJ, Lutz B, Baker D, Dittel BN: Direct suppression of CNS autoimmune inflammation via the cannabinoid receptor $\mathrm{CB}_{1}$ on neurons and $\mathrm{CB}_{2}$ on autoreactive T cells. Nat Med 2007; 13:492-497.

19 Tasker J. Endogenous cannabinoids take the edge off neuroendocrine responses to stress. Endocrinology 2004;145:5429-5430.

20 Stanton-Hicks M, Jänig W, Hassenbusch S, Haddox JD, Boas R, Wilson P: Reflex sympathetic dystrophy - changing concepts and taxonomy. Pain 1995;63:127-133.

21 Bruehl S, Harden RN, Galer BS, Saltz S, Bertram M, Backonja M, Gayles R, Rudin N, Bhugra MK, Stanton-Hicks M: External validation of IASP diagnostic criteria for complex regional pain syndrome and proposed research diagnostic criteria. Pain 1999;81: 147-154.

22 Gerbershagen U: Organisierte Schmerzbehandlung - Eine Standortbestimmung. Internist 1986;27:459-469.

23 Weisaeth L: Torture of a Norwegian ship's crew. The torture, stress reactions and psychiatric after-effects. Acta Psychiatr Scand Suppl 1989;355:63-72.

24 Vogeser M, Hauer D, Christina AS, Huber E, Storr M, Schelling G: Release of anandamide from blood cells. Clin Chem Lab Med 2006; 44:488-491.

25 Grande LA, Loeser JD, Ozuna J, Ashleigh A, Samii A: Complex regional pain syndrome as a stress response. Pain 2004;110:495498.

26 Sparling PB, Giuffrida A, Piomelli D, Rosskopf L, Dietrich A: Exercise activates the endocannabinoid system. Neuroreport 2003; $14: 2209-2211$. 
27 Schelling G, Hauer D, Azad SC, Schmoelz M, Chouker A, Schmidt M, Hornuss C, Rippberger M, Briegel J, Vogeser M: Effect of general anesthesia on anandamide blood levels in humans. Anesthesiology 2006;104:273277.

28 Kaufmann I, Schelling G, Eisner C, Richter HP, Krauseneck T, Vogeser M, Hauer D, Campolongo P, Chouker A, Beyer A, Thiel $\mathrm{M}$ : Anandamide and neutrophil function in patients with fibromyalgia. Psychoneuroendocrinology 2008;33:676-685.

29 Fowler CJ: The cannabinoid system and its pharmacological manipulation - a review, with emphasis upon the uptake and hydrolysis of anandamide. Fundam Clin Pharmacol 2006;20:549-562.

30 Azad SC, Monory K, Marsicano G, Cravatt BF, Lutz B, Zieglgänsberger W, Rammes G: Circuitry for associative plasticity in the amygdala involves endocannabinoid signaling. J Neurosci 2004;24:9953-9961.

31 Connell K, Bolton N, Olsen D, Piomelli D, Hohmann AG: Role of the basolateral nucleus of the amygdala in endocannabinoid-mediated stress-induced analgesia. Neurosci Lett 2006;397:180-184.

32 Marsicano G, Wotjak CT, Azad SC, Bisogno T, Rammes G, Cascio MG, Hermann H, Tang J, Hofmann C, Zieglgänsberger W, Di Marzo V, Lutz B: The endogenous cannabinoid system controls extinction of aversive memories. Nature 2002;418:530-534.

33 Roozendaal B, Quirarte GL, McGaugh JL: Stress-activated hormonal systems and the regulation of memory storage. Ann NY Acad Sci 1997;821:247-258.

34 Pertwee RG: Cannabinoid receptors and pain. Prog Neurobiol 2001;63:569-611.
35 Hohmann AG, Suplita RL, Bolton NM, Neely MH, Fegley D, Mangieri R, Krey JF, Walker JM, Holmes PV, Crystal JD, Duranti A, Tontini A, Mor M, Tarzia G, Piomelli D: An endocannabinoid mechanism for stressinduced analgesia. Nature 2005;435:11081112.

36 Suplita RL, Farthing JN, Gutierrez T, Hohmann AG: Inhibition of fatty-acid amide hydrolase enhances cannabinoid stress-induced analgesia: sites of action in the dorsolateral periaqueductal gray and rostral ventromedial medulla. Neuropharmacology 2005;49:1201-1209.

37 Ullrich O, Merker K, Timm J, Tauber S: Immune control by endocannabinoids - new mechanisms of neuroprotection? J Neuroimmunol 2007;184:127-135.

38 Klein TW, Newton C, Larsen K, Lu L, Perkins I, Nong L, Friedman H: The cannabinoid system and immune modulation. J Leukoc Biol 2003;74:486-496.

39 Cabral GA, Marciano-Cabral F: Cannabinoid-mediated exacerbation of brain infection by opportunistic amebae. J Neuroimmunol 2004; 147:127-130.

40 Kishimoto S, Muramatsu M, Gokoh M, Oka S, Waku K, Sugiura T: Endogenous cannabinoid receptor ligand induces the migration of human natural killer cells. J Biochem (Tokyo) 2005; 137:217-223.

41 Kraft B, Kress HG: Indirect $\mathrm{CB}_{2}$ receptor and mediator-dependent stimulation of human whole-blood neutrophils by exogenous and endogenous cannabinoids. J Pharmacol Exp Ther 2005;315:641-647.

42 Ziring D, Wei B, Velazquez P, Schrage M, Buckley NE, Braun J: Formation of B and T cell subsets require the cannabinoid receptor $\mathrm{CB}_{2}$. Immunogenetics 2006;58:714-725.
43 D’Argenio G, Valenti M, Scaglione G, Cosenza V, Sorrentini I, Di Marzo V: Up-regulation of anandamide levels as an endogenous mechanism and a pharmacological strategy to limit colon inflammation. FASEB J 2006; 20:568-570.

44 Izzo AA, Capasso F, Costagliola A, Bisogno T, Marsicano G, Ligresti A, Matias I, Capasso R, Pinto L, Borrelli F, Cecio A, Lutz B, Mascolo N, Di Marzo V: An endogenous cannabinoid tone attenuates cholera toxin-induced fluid accumulation in mice. Gastroenterology 2003;125:765-774.

45 Di Marzo V, Izzo AA: Endocannabinoid overactivity and intestinal inflammation. Gut 2006;55:1373-1376.

46 Van de Voorde S, Saha B, Mahadevan A, Razdan RK, Pertwee RG, Martin BR, Fowler CJ: Influence of the degree of unsaturation of the acyl side chain upon the interaction of analogues of 1-arachidonoylglycerol with monoacylglycerol lipase and fatty acid amide hydrolase. Biochem Biophys Res Commun 2005;337:104-109.

47 van der Stelt SM, van Kuik JA, Bari M, van Zadelhoff G, Leeflang BR, Veldink GA, Finazzi-Agro A, Vliegenthart JF, Maccarrone M: Oxygenated metabolites of anandamide and 2-arachidonoylglycerol: conformational analysis and interaction with cannabinoid receptors, membrane transporter, and fatty acid amide hydrolase. J Med Chem 2002;45: 3709-3720.

48 Vogeser M, Schelling G: Pitfalls in measuring the endocannabinoid 2-arachidonoyl glycerol in biological samples. Clin Chem Lab Med 2007;45:1023-1025. 